\title{
The development of SUCCEED: urban sustainability assessment tool for developing countries with focus on Nigeria
}

\author{
Job Momoh \\ London South Bank University, London, UK \\ Joseph Chelemu Kangwa \\ School of Built Environment and Architecture, Leeds Metropolitan University, \\ Leeds, UK and \\ Department of Construction, Property and Surveying, London South Bank University, \\ London, UK \\ Chika Udeaja and Jin Ruoyu \\ London South Bank University, London, UK, and \\ Rafiu Dimeji Seidu \\ School of the Built Environment and Architecture, London South Bank University, \\ London, UK
}

\begin{abstract}
Purpose - Developing countries are currently on the verge of adopting principles used in achieving a sustainable urban future. As the urban population increases due to factors like urban-rural migration, increase in birth rate, migration, industrialisation, commercialisation, amongst others, there is a drastic need to adopt sustainability principles within urban spaces. To understand how sustainability can be achieved, there is a need to recognise how developed countries have designed assessment tools that work within their context which can inform how developing countries can work on their assessment tool. Urban neighbourhood sustainability assessment tools are used to reflect on the overall goal of the project and the most important indicators needed to be implemented within the project. Sustainability indicators are used to measure the levels and progress at which sustainability has been implemented within a project based on the data collected and these results can be used to make informed decisions. The purpose of this paper is to investigate the development of urban sustainability assessment tool.

Design/methodology/approach - This research investigates the techniques utilised in developing an urban sustainability assessment tool Sustainable Composite Cities Environmental Evaluation and Design (SUCCEED-ND) tool within the Nigerian context. The data instrument used includes a questionnaire survey that sampled 50 correspondents, and the results were used to develop an urban assessment tool tailored for the Nigerian countries.

Findings - The findings used social, environmental, economic and planning sustainability dimensions in the design of the assessment tool which composes of 21 core sustainability indicators and 105 indicators to develop SUCCEED-ND tool.

Originality/value - This work developed the first urban sustainability assessment tool for the Nigerian urban environment. The result is meant to evaluate and implement sustainability within existing and proposed neighbourhood development.
\end{abstract}

Keywords Developing countries, Sustainability dimensions, Sustainable indicators, Urban development, Urban sustainability assessment

Paper type Research paper

\section{Introduction}

Developing countries are currently experiencing a drastic increase in urban growth which is now a global problem as this growth does not embed sustainability principles (Wu, 2014). The result of this uncontrolled rapid growth is the prediction that two-thirds of the global development of SUCCEED

Received 6 April 2021

Revised 22 June 2021 8 September 2021 Accepted 15 September 2021 
population will live in cities by 2050 (UNDESA, 2015). It is very important to note that cities in the 21st century have a huge environmental impact due to the urban populace and the amount of natural resources that is been utilised. Globally, it is stated that 50 million people move into cities each year which would create urban problems (Rahagen and Groth, 2012). Hence, it is vital to plan for future urban spaces that adhere to sustainability principles. Research conducted showcases that environmental sustainability is very pressing; as a result, $60 \%$ of carbon dioxide is been produced in the world (UN Habitat, 2009). It is also of concern that in developing countries' social and economic dimensions of sustainability are also pressing concerns as these three dimensions form the base for a truly sustainable urban future. This has led to a global outcry to achieve urban sustainability which can be accomplished by using a clear set of goals, targets and progress mapping reports to achieve urban sustainability. This has created sustainability assessment methodologies which is a combination of procedures, methods and tools by which a policy, programme or project may be assessed as to its potential, economic, social and environmental impacts as well as the distribution of those impacts within a population, a geographical area, a market or across a generation (Curwell et al., 2005; p. 21; Haapio and Viitaniemi, 2008).

Urban sustainability is a principle that aims to minimise environmental damage alongside a steady economic base where resources are allocated fairly, and the people have a strong sense of community participation in decision-making to better the society. In order words, it is a cross-cutting subject across environmental, social and economic sustainability (Wang et al., 2016). Urban sustainability is a pressing and growing topic in which sustainability assessment methods are being utilised in developing urban sustainability assessment tools. Urban sustainability assessment has been advocated as a vital tool in achieving sustainable urban futures based on the principles that drive this topic (Sharifi and Murayama, 2015; Aguiar et al., 2020). Urbanisation techniques such as urban planning and design are different from a global perspective from one region to another based on sustainability indicators which are designed centred on a specific context. These sets of indicators are associated with the population, density, employment, services availability and quality of space within a city. Currently, developed urban sustainability assessment tools existing includes Building Research Establishment Environmental Assessment Method (BREEAM) ND which is UK's foremost assessment tool, HQE developed in France, Comprehensive Assessment System for Building Environmental Efficiency (CASBEE) developed for Japan, Green Star for Australia and readapted for developing economies like South Africa (Reed et al., 2011). This shows that assessment tools have been designed and tailored to their regions based on the data collected within their context. This paper aims to identify vital indicators needed in the development of Nigerians foremost urban sustainability assessment tool. There is also a pressing need for Nigeria to own its foremost assessment tools designed to suit the Nigerian context as there is no known existing tool used in Nigeria. The assessment tool would be designed using both mixed methodology using both qualitative and quantitative data sets and a questionnaire will be used to streamline the indicators while literature review will be used to underpin the research objectives.

This research paper presents the need to develop an urban neighbourhood assessment tool that should be tailored to the Nigerian context within the Introduction section. The second section provides a brief overview of the various urban assessment tools. The third section focusses on the importance of sustainability indicators in the Nigerian context and how it shapes the development of Sustainable Composite Cities Environmental Evaluation and Design (SUCCEED) tool based on some set of sustainability indicators. The fourth section reviews the data from questionnaires collected and correspondents from participants to develop a sustainable urban assessment tool for the Nigerian context. Finally, the conclusion summarises the entire paper and recommends how sustainability assessment can be a vital tool in achieving a truly sustainable urban future. 


\section{Urban sustainability assessment}

\section{Urban problems in Nigeria and the need for sustainability assessment}

Nigeria is the most populated country in Africa with over 200 million people living within the country (Idowu, 2013). The level of poverty and instability of the country has led to a high level of rural-urban migration. This migration and resultant urbanisation have been argued to have brought about a variety of problems such as poor security, extreme crime rates, high unemployment, high poverty rate, slums, insecurity and environmental degradation amongst others (National Planning Policy, 2012). This lack of adequate long-term planning for the development of cities and rural areas is partly due to the insufficient capacity, resources and lack of up-to-date data to implement proper planning. The use of urban sustainability assessment tools has been proven to help enhance the quality of space and the life of its occupants. A well-implemented assessment tool can improve urban degradation, overstretched facilities, sustainable living, employment level and adequate planning. In addition, assessment tools can help initiate "sustainable development goals" (SDG) which are meant to improve health, poverty, energy, climate quality, equality, economy, land use, urban transportation, crime, public policy and housing.

\section{Development of urban sustainability assessment}

To achieve a truly sustainable environment within urban spaces, an assessment rating methodology needs to be developed. The use of a sustainability assessment tool measures the performance of an urban environment to create a comparison of the overall assessment with other urban dwellings (Fowler and Ranch, 2006). The factors needed to design an assessment method is based on using theoretical approaches, the practicality of this scheme which is based on a specified context/region and specified space (Building, urban scale or community planning) (Cole, 1999; Aguiar et al., 2020). The assessment method is the most vital aspect of an urban sustainability assessment. This assessment is based on an allocated criterion and performance scores given to each sustainability indicator used in designing the model.

Although it is important to note that these concepts are relatively new, there have been series of assessment methods available which includes assessment frameworks, rating toolkits, life cycle assessment and certification systems. Based on this, a range of methods have been established for specific regions, and it is designed based on urban factors which include sub/core categories, criteria and sustainability indicators in accordance to geospatial variables relating it to the urban need of various countries (Moussiopoulos et al., 2010). From the onset, some international initiative was developed and used by various countries to address pressing issues revolving around climate change and global warming alongside the three tiers of sustainability. A good example is the International Council for Local Environmental Initiatives (ICLEI) which was developed in 1990 to provide hands-on training, consultancy and assistance to governmental agencies in the adaptation of local sustainable development (Lindseth, 2004). Another example was Agenda 21 which was an action plan used at the local, regional and international level to promote the global sustainability of urban spaces. This was developed by the United Nations Conference on Environment and Development (UNCED) in 1992 (UN 1992). Aalborg commitments then came in 1994 which was developed for European cities and towns to adopt an overall guideline for sustainable development (Zilans and Abolina, 2007). Driving forces, pressures, the state of the environmental impacts and response (DPSIR) framework, which focussed on enhancing environmental sustainability, was developed in 1995 and then implemented by the European Environment Agency (EEA) (Svarstad et al., 2008). All these systems developed targeted conserving the global ecosystem and achieving urban sustainability from both regional and global perspectives.

These systems gave birth to too many reports based on urban sustainability assessment methods which have become a vital research area and fundamental framework used in most

\section{The \\ development of SUCCEED}


countries. The introduction of CASBEE-UD, BREEAM Communities and Leadership in Energy and Environmental Design (LEED-ND) which were based on individual countries attracted lots of attention because they expanded from building-scale to urban-scale assessment tools. This also made other countries develop their assessment tools based on its region and context, for example Pearls Community (PCRS), Green Star Communities, Green Mark for Districts, ESTIDIMA, GSAS Neighbourhoods and DGNB for Urban Development (Castanheira and Braganca, 2014; Sharifi and Murayama, 2015).

\section{Origin of urban sustainability assessment}

The need for achieving sustainable development began in the late 1980s, as there were pressing concerns in designing sustainable urban futures. This resulted in having the first studies on urban sustainability assessment published in the 1990s. This concept came to existence during the Brundtland report in 1987 and the Rio declaration on Environment and Development in 1992 when the need for promoting urban sustainability was emphasised alongside the SDGs (Sharifi, 2021). From that instance, there has been pressing needs on scientists and policymakers to develop urban sustainability based on major international reports and policy frameworks. BREEAM was classed as the foremost sustainability assessment rating tool developed in the United Kingdom by the BRE known as the Building Research Establishment in 1990. This tool kit aims to create an environmental measurement tool for buildings (Roderick et al., 2011). This led to the development of LEED which was designed for the USA in 1998, Green Star was developed for Australia in 2003 and CASBEE was developed for Japan in 2004. This assessment was used to support the performance improvements in buildings, and other versions were developed focussing on city and neighbourhood scale. The essence of these systems is to create a report sheet which enhances environmental awareness and provides a standardised framework that gives key direction on how the buildings and construction industry can embed sustainability principle within the project focussing on social, environmental and economic indicators (Reed et al., 2011; Ameen and Mourshed, 2019). Diverse countries have identified the need to develop an assessment tool tailored for individual contexts as well as to help key stakeholders to embed sustainability (Wong and Abe, 2014).

In the process of conducting an assessment, a project is considered to have achieved a certain degree of sustainability when it is interwoven with all the key dimensions of sustainability. These include minimising the impact on the usage of natural resources, emissions/energy consumption, utilising environmentally friendly materials, waste reduction, reducing water use and waste recycling/reuse. Other indicators that could be added include site optimisation, cultural preservation, healthy indoor climate, safety, employment, economic growth, job opportunities and planning amongst others (Happio, 2012). Sustainability assessment aims to collate information and reports for decisionmaking during the building design, construction and operation. The sustainability score will depends on different criteria or indicators, analysed, valued and adopted (Braganca et al., 2010).

\section{Global urban sustainability assessment tools}

It is vital to note that when it comes to the development of rating tools, they tend to have a similar approach as a result of the assessment of buildings and urban spaces against the sustainability indicators and sub-categories which has been achieved. Also, these points are weighted which are used to identify the final result for the assessed project based on the rating classification (Roderick et al., 2011). Sustainability assessment tools are developed to measure the level of sustainability achieved within various schemes like offices, educational 
buildings, factories, residential neighbourhood development and city-scale projects. It is also imperative to note that the design of these tools is based on city councils, professional bodies and agencies that regulate building standards within a region. Hence, it would have to go through a high level of scrutiny, research, enquiry-led design, credibility and pragmatism to achieve higher sustainability standards (Sleeuw, 2011). Table 1 identifies a clear comparison between BREEAM, LEED, Green Star and CASBEE looking at some vital sets of criteria (Reed et al., 2011).

Arguments made by scholars have clearly stated that most assessment tools have mutual environmental aim with a slight difference in their compositions for example methodologies, scope, assessment rating, metric system and certification processes. Sleeuw (2011) stated that although an assessment template would enhance benchmarking of building and urban development within different countries the main problem remains that diverse contexts would showcase different sustainability needs which would affect the level of prioritisation of indicators. Therefore, having a uniform sustainability standard for example neighbourhood sustainability assessment would be very difficult to achieve (Reed et al., 2011; Sleeuw, 2011). This deduction has led to a clearer understanding that some criteria and categories will be emphasised in some tools, while others will remain dormant or not a priority (Kyrkou et al., 2011).

\begin{tabular}{|c|c|c|c|c|c|}
\hline & BREEAM & LEED & Green Star & CASBEE & \\
\hline Launch date & 1990 & 1998 & 2003 & 2004 & \\
\hline Ratings & $\begin{array}{l}\text { Pass/Good/Very } \\
\text { good/Excellent/ } \\
\text { Outstanding }\end{array}$ & $\begin{array}{l}\text { Certified/Silver/Gold/ } \\
\text { Platinum }\end{array}$ & $\begin{array}{l}\text { One/Two/ } \\
\text { Three/Four/ } \\
\text { Five/Six star }\end{array}$ & $\mathrm{C} / \mathrm{B}-/ \mathrm{B}+/ \mathrm{A} / \mathrm{S}$ & \\
\hline Weightings & $\begin{array}{l}\text { Applied to each issue } \\
\text { category (consensus } \\
\text { based on scientific/ } \\
\text { open consultation) }\end{array}$ & $\begin{array}{l}\text { All credits equally } \\
\text { weighted, although the } \\
\text { number of credits } \\
\text { related to each issue is } \\
\text { the weighting factor }\end{array}$ & $\begin{array}{l}\text { Applied to each } \\
\text { issue category } \\
\text { (industry- } \\
\text { survey based) }\end{array}$ & $\begin{array}{l}\text { Highly complex } \\
\text { weighting system } \\
\text { applied at every } \\
\text { level }\end{array}$ & \\
\hline $\begin{array}{l}\text { Information } \\
\text { gathering }\end{array}$ & $\begin{array}{l}\text { Design/management } \\
\text { team or assessor }\end{array}$ & $\begin{array}{l}\text { Design/management } \\
\text { team or accredited } \\
\text { professional }\end{array}$ & $\begin{array}{l}\text { Design team } \\
\text { design }\end{array}$ & $\begin{array}{l}\text { Design team } \\
\text { design/ } \\
\text { management team }\end{array}$ & \\
\hline $\begin{array}{l}\text { Third-party } \\
\text { valuation }\end{array}$ & BRE & $\mathrm{N} / \mathrm{A}$ & $\begin{array}{l}\text { GBCA (Green } \\
\text { Building } \\
\text { Council of } \\
\text { Australia) }\end{array}$ & $\begin{array}{l}\text { Third-party } \\
\text { agencies e.g. JSBC }\end{array}$ & \\
\hline $\begin{array}{l}\text { Certification } \\
\text { labelling }\end{array}$ & BRE & USGBC & GBCA & JSBC & \\
\hline Update process & Annual & As required & Annual & As required & \\
\hline Governance & $\begin{array}{l}\text { UK Accreditation } \\
\text { Service }\end{array}$ & USGBC & GBCA & JSBC & \\
\hline $\begin{array}{l}\text { Required } \\
\text { qualification }\end{array}$ & $\begin{array}{l}\text { Competent persons } \\
\text { scheme }\end{array}$ & Passed exam & $\begin{array}{l}\text { Training } \\
\text { scheme and } \\
\text { exam }\end{array}$ & N/A & \\
\hline Assessor & $\begin{array}{l}\text { Carry out at least one } \\
\text { assessment per year }\end{array}$ & No $\mathrm{CPD}$ requirements & $\begin{array}{l}\text { Status renewed } \\
\text { every three } \\
\text { years }\end{array}$ & N/A & \\
\hline $\begin{array}{l}\text { Assessment } \\
\text { collation fee as } \\
\text { at } 2016\end{array}$ & $\begin{array}{l}£ 2,000-£ 10,000 \\
(\$ 3,971-19,857)\end{array}$ & Up to $£ 37,770(\$ 75,000)$ & $\begin{array}{l}£ 2,015-4,030 \\
(\$ 4,002-8,004)\end{array}$ & Unknown & Table 1 \\
\hline $\begin{array}{l}\text { Certification fee } \\
\text { as at } 2016\end{array}$ & $\begin{array}{l}£ 740-£ 1,500 \\
(\$ 1,469-2,979)\end{array}$ & $\begin{array}{l}£ 1,133-£ 11,331 \\
(\$ 2,250-22,500)\end{array}$ & $\begin{array}{l}£ 2,550-£ 7,185 \\
(\$ 5,063-14,268)\end{array}$ & Unknown & $\begin{array}{l}\text { Comparison of } \\
\text { BREEAM, LEED, } \\
\text { Green Star and }\end{array}$ \\
\hline \multicolumn{5}{|c|}{ Source(s): Momoh (2016) } & CASBEE \\
\hline
\end{tabular}


BREEAM was developed in 1990, but in 2009, it was planned that it needed to include a neighbourhood assessment tool which resulted in the development of BREEAM Communities (BRE, 2017). This tool aimed to develop sustainable communities with a focus on urban development projects addressing environmental, economic and social factors within urban spaces. It creates an opportunity for stakeholders to understand the extent to which sustainability indicators can influence decision-making for the local community as well as meeting the needs of the existing and future populace alongside improving the quality of life and well-being (BRE, 2008; BRE, 2017). The main categories are Governance, Social and Economic wellbeing, Resources and Energy, Land use and Ecology.

\section{LEED-ND}

LEED was developed by the US Green Building Council in 1998. The main focus of this tool is to create a standard assessment tool for building performance optimisation in other to achieve sustainability goals alongside improving the green building standards (Zimmerman and Kibert, 2007). LEED-ND was developed in 2007 to meet the need in designing urban spaces to meet environmental issues and land-use in the USA by improving community design and land spatial use. It uses the principles of smart growth, site selection, infrastructure provision, house affordability and landscape to develop the tool (USGBC, 2011). LEED-ND emphasises on the main categories which are neighbourhood's model/ building design alongside green infrastructure and buildings.

\section{CASBEE-UD}

CASBEE was developed by the Japanese Sustainable Building Consortium (JSBC) as an assessment tool to measure the environmental performance of buildings in 2001 (Reed et al., 2011). This led to the creation of CASDEE-UD which was released in 2007 with the aim was to improve sustainability within cities and regional environment linking it to building laws and systems for urban spaces to have comprehensive design systems (IBEC, 2017). CASBEE places more emphasis on the functionality of services for designated spaces and social infrastructure (Alqahtany, 2013).

\section{Green Star for communities}

Green Star was developed by the Green Building Council of Australia in 2003. After which Green Star communities was created in 2007 to measure sustainability within urban neighbourhoods to raise the awareness and the benefits of green buildings in reducing the environmental impact of development and to stand out with regards to environmental leadership (ABGR, 2015). It is also been adopted within South Africa and New Zealand as they have similar climatic factors and weather conditions (GBCA, 2012). Green Star focusses more on the natural environmental quality, place-shaping and green infrastructure.

\section{SuBETool model}

SuBETool was developed in 2009 by a consultancy company called Hilson Moran with the expertise of Dr. Husam Alwaer. The tool is used to measure the overall performance of the master plan in cities. The tool is formulated based on the three pillars of sustainability but focusses on infrastructure and the entire master plan itself which affects the long-term sustainability impact (Alwaer et al., 2013).

\section{SUPD model}

Sustainable Urban Planning Development (SUPD) framework was proposed by Ali Alqahtany in search of creating a new assessment scheme for the Gulf region. This tool 
comprises of the combination of environmental, social, economic, information technology and planning dimensions, which was further sub-divided into various indicators (Alqahtany, 2013).

\section{Green economy framework}

This framework highlights the current policies and programmes taken to achieve sustainable development. The green economy policy is based on this framework from national vision 20:2020, MDG, Transformation Agenda, Local Agenda 21, UNDP framework, EIA Act amongst others (FGN, 2012).

\section{Sustainability indicators}

The use of sustainability indicators in the context of Nigerian urban spaces

Developed societies have been able to provide basic human needs for their citizens, and in some cases where the population is less than the gross domestic product (GDP), the standard of living parameters have been exceeded. In such cases, emphasis would be placed on maintaining these standards, as well reducing depletion of natural resources and damage to the environment (Loh, 2000; Gibberd, 2002). In developing societies, however, the average standard of living is much lower in comparison to developed societies and, in some cases, human needs cannot be met; hence, it is argued that development should aim at addressing basic needs while circumventing negative environmental impacts (Gibberd, 2002). In Nigeria, there has been a various range of policies, initiatives and schemes established to help support this approach by governmental and non-governmental agencies/organisations. Most of the schemes, like Vision 2010, have failed to work based on inappropriate implementation strategies for example vision 2010 was meant to improve urbanisation growth, unemployment, education, economy, infrastructure to a certain percentage, but the level of growth as expected has not been actualised (Ajayi and Chris, 2005).

For the Nigerian urban spaces, the use of sustainability indicators can be achieved when a proposed framework has been developed, tested and proven to work. Also, the implementation could either focus on the top-bottom approach or the bottom-top approach. The three dimensions of sustainability can be designed to have core indicators and then subindicators. The selection of sustainability indicators for the Nigerian urban environment would be based on pressing issues raised earlier - mostly standard of living, the socioeconomic impact of the indicators and minimising negative environmental impact. Assessing and implementing sustainability in Nigerian urban spaces would require an effective and easily adaptable approach. This approach can be the initiation of an assessment tool or framework aligned with the stated objectives. This assessment and a set of processes will ensure that the scheme is used to guide and suggest actions in the buildings and construction sector (Loh, 2000; Gibberd, 2002). This conscious approach must be established to make sustainable development an explicit goal.

\section{Sustainable Composite Cities Environmental Evaluation and Design tool (SUCCEED Nigeria neighbourhood design)}

This proposed framework is designed based on two major fundamentals. First, the current knowledge is retrieved from an analysis of various academic research papers and reports to the concepts of sustainable urban planning, sustainable urbanism and indicators from sustainable urbanism; and second, knowledge is acquired from the analysis of various existing frameworks and assessment tools based on their merits and demerits as well as their strengths and weaknesses using a sound methodological approach. Finally, the tool is subject to validation. 
In line with the analysis of the existing assessment tools, a detailed proposal for an assessment framework for developing countries like Nigeria will increase the achievement of sustainable urban futures. The proposed tool titled SUCCEED tool focusses on emerging markets where sustainability is starting to become a priority. It also develops a new framework that encourages the successful implementation of sustainability. The tool will offer a comprehensive assessment that evaluates the sustainable design and performance of any major master plan (mainly neighbourhood design scale). The SUCCEED tool will help to provide a framework that incorporates the four main dimensions of sustainability which are sociocultural, environmental and economic, and a fourth dimension is planning sustainability which has recently been incorporated and adapted into sustainability.

This research is based on the analysis of six main models, LEED, BREEAM, SUBETool, Green Star, Green Economy Indicators and CASBEE. The results and findings obtained through the literature review have emphasised the need for an effective framework for sustainable urban futures based on their strengths, weaknesses, obstacles and challenges. The selection of indicators will be based on the following question: Who will finance the project? How will it sustain itself? Would it be affordable for every common individual? (That is where social equity comes into play.) Are there measures put in place where people can pay for this development over a long period? Can this development provide permanent job opportunities? Are these developments affordable for low and middle-income earners? Can this assessment model be used in other developing countries? These pressing issues are the most pertinent indicators to be explored further through data collection and analysis (European Urban Knowledge Network, 2014).

\section{Selected sustainable indicators for the Nigerian context}

Most existing assessment tools have been designed based on the context in which sustainability is to be assessed and measured. Therefore, it is important to note that assessment tools have been developed concerning features within a particular country and region to be focussed on (Curwell et al., 2005, p. 35).

Studies have shown that there are two approaches to measuring sustainability. The first approach is through the selection of individual fields which are measured by the use of sustainability indicators, while the second deals with the overall progress which aims to achieve sustainability through a combination of individual fields with regards to interaction (Warhurst, 2002). Sustainability indicators help those involved in planning to be more informed about the impact of future developments based on assessments taking from previous developments (Balsas, 2004). The compilation of the right set of indicators for a context is a thorough process with a structured framework or consensus on what urban sustainability should be (Deakin et al., 2002; Lombardi and Cooper, 2009). The use of indicators presents an evaluation of performances of projects, communities, neighbourhoods, buildings, infrastructures and countries as they relate to the three dimensions of sustainability (economic, environmental and sociocultural) (Xing et al., 2009). The most pressing issue in measuring the sustainability of communities is to create a single framework of indicators corroborating the three dimensions. Moreover, since this is a collaborative process of multi-stakeholders, the chosen indicators must communicate with the variety of different actors, players and disciplines involved (D'Acci and Lambardi, 2010, p. 21; Todd and Geissler, 1999, p. 249).

Six main sustainability assessment tools were used in the design of SUCCEED (a combination of LEED, BREEAM, Green Star, CASBEE, SUPD, SuBETool and Green Economy Framework). Four are internationally recognised, while the remaining two are emerging methods (see Figure 1 and Table 2). In line with the above assessment tools which have been analysed and synthesised, SUCCEED tool is to be designed based on four 


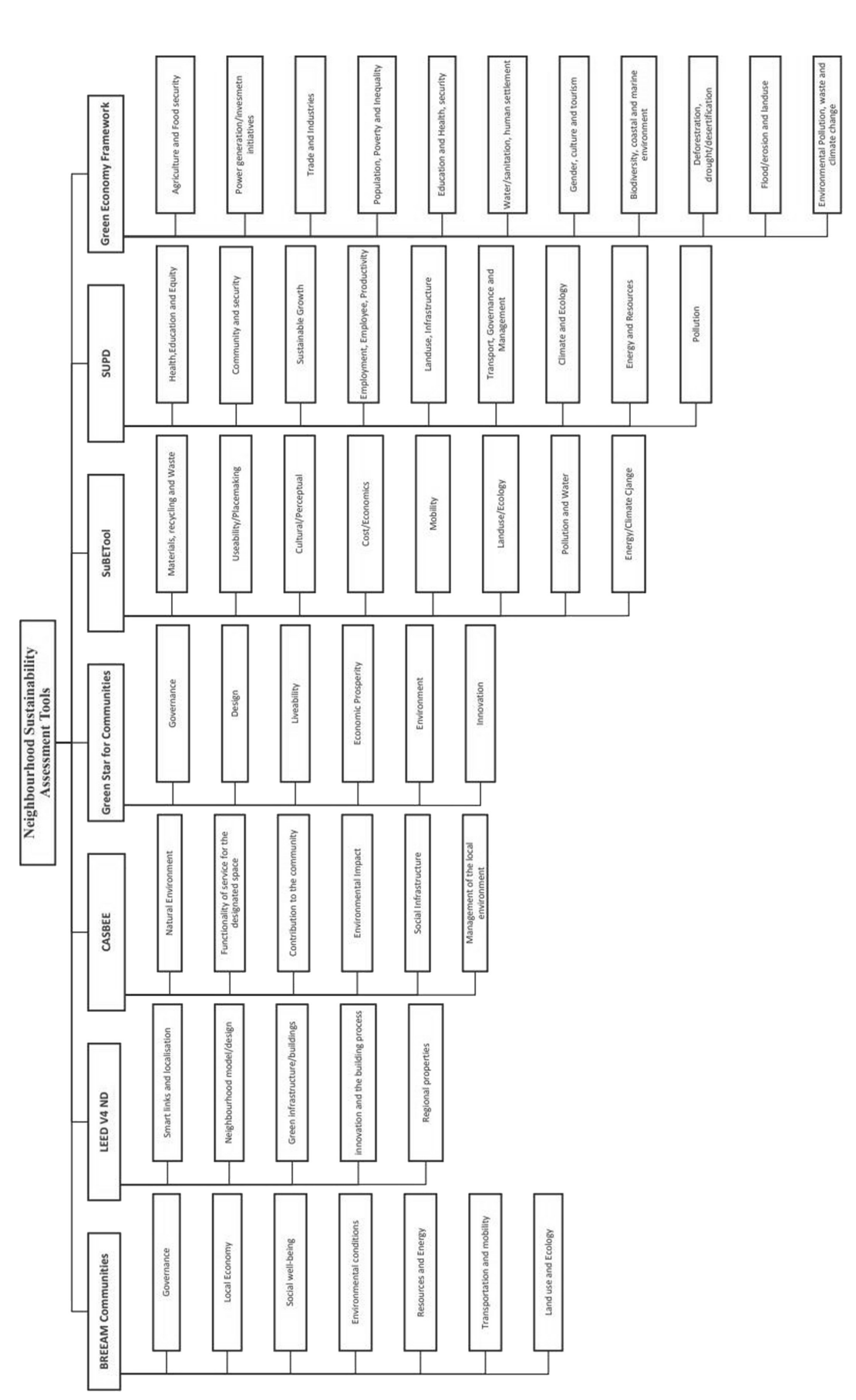

The development of SUCCEED

Figure 1 Mapping out all the key sustainability indicators used in the neighbourhood sustainability assessment tools 


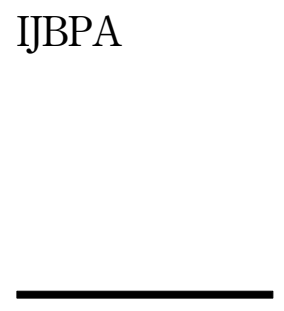

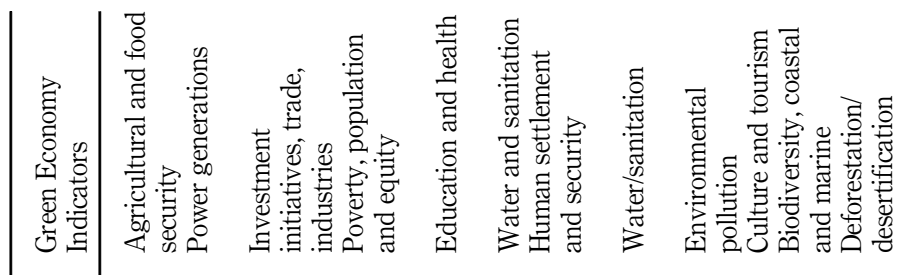

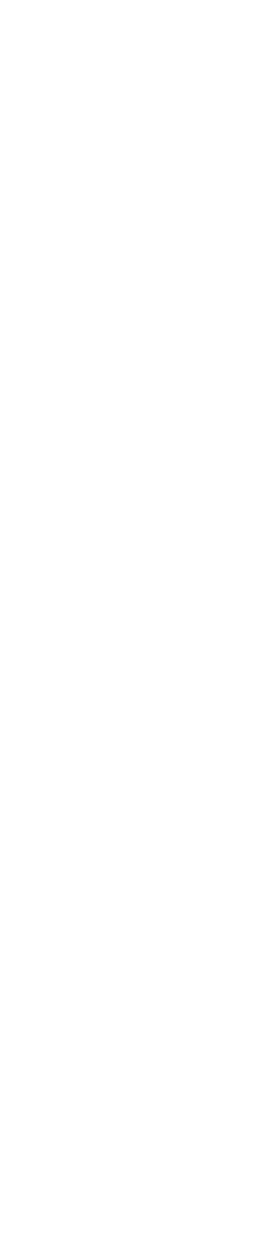

Table 2.

Main core categories in BREEAM, LEED,

Green Star, SuBETool, SUPD, CASBEE and Green Economy

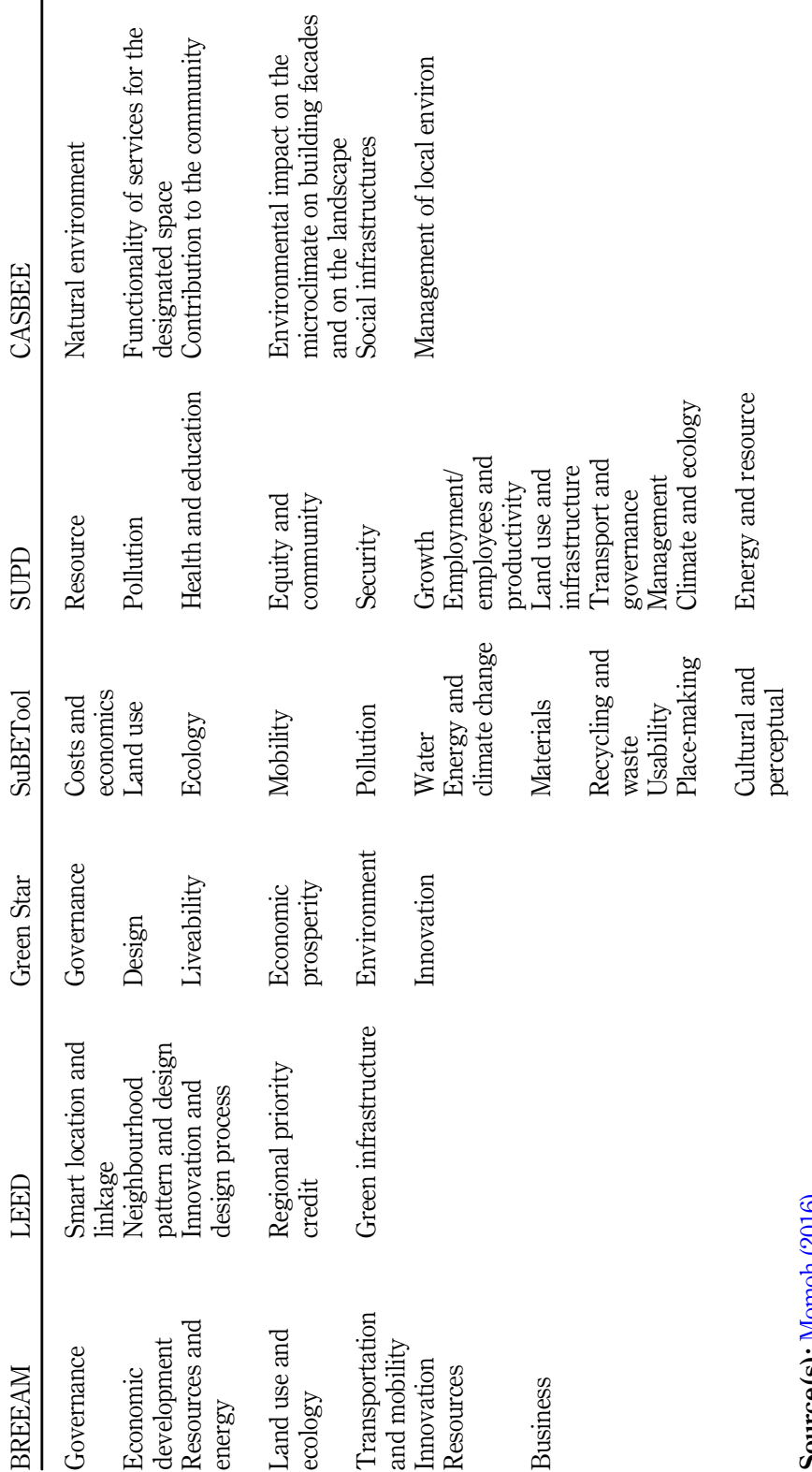


dimensions of sustainability - environmental, socialcultural, planning and economic sustainability.

\section{Methodology}

The researcher selected both the core categories and sub-categories' indicators which were used in developing SUCCEED assessment tool. The collation of the key criteria or subcategories was adopted from LEED-ND, BREEAM, Green Star, SUPD, SuBETool, SUPD, CASBEE and Green Economy Indicators. These criteria were selected and merged to form a total of 105 sub-categories' indicators. This selection was also grouped under the main dimensions so that the main dimension can relate to the core categories, and the core categories can then relate to the sub-categories. The indicators selected are specifically chosen for their adaptation in developing countries.

This survey was used to identify which main indicators and sub-categories of sustainability which key professionals and non-professionals (no membership/chartership) consider important when evaluating new or existing development and also to create a process in which perceptions can influence thinking of community planning and design (Sharifi, 2021). This will clarify any areas of uncertainty and allow those responsible for decisionmaking to offer additional information as well as to validate the proposed assessment scheme creating a more pragmatic tool that will be influenced by the data collected from professionals, stakeholders, end-users and, lastly, the general community (Sharifi, 2021; Wang et al., 2016). The sustainability indicators are rated according to six categories are as follows: (1) Not important at all; (2) Of some importance; (3) Important; (4) Very important; (5) Extremely important and (6) Necessary in the near future. The survey was conducted with over 50 participants from various fields and people within the local communities as well which helped in establishing a robust assessment tool to be refined at the end of this exercise. The data were mainly quantitative, and the participants fell within three groups - academics, practitioners and government officials. All participants had undergraduate or Higher National Dipoma (HND) certificates, while 23 participants had masters and 10 had doctorate degrees. A significant percentage of the participants are based mainly in the Nigerian system (either in tertiary institutions, government agencies and private practices), while some were contacted across the globe. The indicators selected were based on how the participant rated their level of importance. The reason for using questionnaires is that it can obtain information from a large number of people while users spread over a wide geographical area and can be used in advance of an interview.

\section{Dephi-based validation result}

The participants were asked to select the level of priority of each dimension to the Nigerian context. A total of 65 people were contacted for this research; of these, 50 agreed to participate in this project. Delphi method or technique is a structured communication technique that was designed as a systematic, interactive forecasting method that depends on a panel of experts (Harold and Murray, 1975). The Delphi method was used to enhance the results that are based on the results of multiple rounds of questionnaires sent to a panel of experts. Some rounds of questionnaires are sent out to the group of experts, and the anonymous responses are aggregated and shared with the group after each round. Two rounds of the Delphi technique were completed, and the entire process of conducting the questionnaire was carried out. The two rounds of Delphi-based validation helped in streamlining the assessment method and to create a list of indicators that were seen to be vital for the Nigerian context. Data analysis was carried out using Microsoft Excel, and the graphs generated from the questionnaires showcase the analysis of the overall perception of 50 participants who took part in this exercise. Also, the table within each sustainability category shows that the mean value and development
of SUCCEED

The 
standard deviation for each dimension would also influence the results and are used to develop the grading criteria. The mean is the total of the numbers divided by how many numbers there are, while standard deviation is a measure of how spread numbers are.

$$
\begin{gathered}
\bar{X}=\frac{\sum f X}{\sum f} \\
S=\sqrt{\frac{\sum X^{2} f}{\sum f}-\left(\frac{\sum X f}{\sum f}\right)^{2}}
\end{gathered}
$$

\section{Analysis, results and discussions \\ Environmental sustainability}

Environmental sustainability is defined as the ability to maintain the factors, practices or qualities that are valued within the physical environment which contributes to the quality of the environment on a long-term basis (Allen, 2009, p. 2). Six main indicators were selected from a sound methodological approach; these are pollution, water, energy, materials (resources/waste), ecology and climate. Based on the results produced, it was understood that the highest amount of importance was from water and energy. Material came third followed by pollution, climate and lastly ecology.

The results of the questionnaires support the fact that more emphasis should be placed on these main indicators which are water and energy. Thus, emphasis should be placed on management alongside the generation of additional renewable energy and alternative water supplies to complement both energy and water supplies, respectively. Climate change, pollution and ecology are areas that have not been taken into serious account in Nigeria although slight traces of action in these areas have been seen in some projects. Ecology in this analysis has shown a decline and, in relation to importance and irrelevance, although it is one of the key areas that sustainable urbanism preaches.

Based on this research, it was gathered that participants did not prioritise indicators in environmental sustainability because of various issues as stated below.

(1) Awareness: There have not been rigorous campaigns, research, government initiatives geared around these pressing issues.

(2) Social/economic condition: The current economic conditions state that an average citizen lives on less than 1 dollar (450 Naira) a day which suggests that living standards are very poor just to survive, so emphasis should be led on economic status.

(3) Environmental sustainability adaptation: Sustainability is currently of growing concern in developing communities, and it is not seen as a priority. It is also perceived as expensive without adding profit value to the developer.

The mean values for the categories of environmental dimension are in the range of 3.32 and 4.48, while the standard deviations for the categories are in the range of 0.769 and 1.61 which means that there is a satisfactory consensus. The decrease in the standard deviation means that the experts show a movement toward convergence and consensus (Vidal et al., 2011). Table 3 presents the mean values and standard deviations for all categories under the environmental dimension as well as their criteria. Figure 2 states the graphs of all identified environmental sustainability categories and sub-categories.

\section{Economic sustainability}

Economic sustainability can be generally defined as the ability of an economy to support or sustain a defined level of economic production, indefinitely (McKenzie, 2004). In relation to the 


\begin{tabular}{|c|c|c|c|c|c|}
\hline $\begin{array}{l}\text { Sustainability } \\
\text { dimension }\end{array}$ & Core categories & Sub-categories & Mean & $\begin{array}{l}\text { Standard } \\
\text { deviation }\end{array}$ & developmen \\
\hline \multirow{33}{*}{$\begin{array}{l}\text { Environmental } \\
\text { sustainability }\end{array}$} & \multirow[t]{4}{*}{ Pollution } & Water pollution & 4.48 & 0.76785 & \\
\hline & & Noise pollution prevention & 3.84 & 0.94573 & \\
\hline & & Air quality enhancement & 4.26 & 0.99619 & \\
\hline & & Pollution innovation & 4.32 & 1.02839 & \\
\hline & \multirow{5}{*}{$\begin{array}{l}\text { Materials resources, } \\
\text { waste }\end{array}$} & Local renewable materials & 4.28 & 0.93722 & \\
\hline & & Recycling and innovation & 4.24 & 0.83809 & \\
\hline & & $\begin{array}{l}\text { Site waste management } \\
\text { schemes }\end{array}$ & 4.00 & 1.28062 & \\
\hline & & Storage of recycled waste & 4.00 & 1.14891 & \\
\hline & & $\begin{array}{l}\text { Use of biodegradable } \\
\text { materials }\end{array}$ & 4.24 & 1.03072 & \\
\hline & \multirow[t]{7}{*}{ Water } & Flood risk & 4.10 & 1.06301 & \\
\hline & & Water quality & 4.46 & 0.7800 & \\
\hline & & Erosion control & 4.34 & 0.92973 & \\
\hline & & $\begin{array}{l}\text { Responsible water supply } \\
\text { initiatives }\end{array}$ & 4.32 & 0.88181 & \\
\hline & & Waste-water management & 4.08 & 1.01666 & \\
\hline & & Smart metring water & 3.60 & 1.29615 & \\
\hline & & $\begin{array}{l}\text { Reduction in water } \\
\text { consumption daily }\end{array}$ & 3.26 & 1.61009 & \\
\hline & \multirow[t]{6}{*}{ Ecology } & Biodiversity & 3.74 & 0.98994 & \\
\hline & & $\begin{array}{l}\text { Ecological appraisal/ } \\
\text { enhancement }\end{array}$ & 3.64 & 1.10923 & \\
\hline & & Minimising ecological impact & 3.78 & 1.044796 & \\
\hline & & $\begin{array}{l}\text { Ecological value } \\
\text { improvement }\end{array}$ & 3.78 & 1.044796 & \\
\hline & & Diversity and preservation & 3.84 & 1.02684 & \\
\hline & & Use of natural topography & 3.32 & 1.21012 & \\
\hline & \multirow{5}{*}{ Energy } & Energy-efficient building & 4.30 & 1.15326 & \\
\hline & & Passive/active designs & 4.20 & 1.28062 & \\
\hline & & $\begin{array}{l}\text { Renewable energy } \\
\text { generation/use }\end{array}$ & 4.30 & 1.06301 & \\
\hline & & Urban grid optimisation & 4.16 & 1.10199 & \\
\hline & & Consumption management & 4.22 & 1.06377 & \\
\hline & \multirow[t]{6}{*}{ Climate } & Climate emissions & 3.96 & 1.34848 & \\
\hline & & $\begin{array}{l}\text { Global warming control } \\
\text { measures }\end{array}$ & 4.26 & 1.05470 & \multirow{5}{*}{$\begin{array}{r}\text { Table 3. } \\
\text { Mean/standard } \\
\text { deviations } \\
\text { (environmental } \\
\text { dimension) }\end{array}$} \\
\hline & & Flood risk mitigation & 4.48 & 0.98468 & \\
\hline & & Solar radiation & 4.12 & 1.05148 & \\
\hline & & Climate change & 3.96 & 0.91564 & \\
\hline & & Resiliency & 3.48 & 1.20399 & \\
\hline
\end{tabular}

built environment, it is a combination of various issues which includes how the development can enhance factors like employment opportunities, growth, urban expansion, affordability of housing schemes, low-cost production of housing, affordable building materials and techniques, amongst others. In most developing countries in Africa, sustainability is seen as a vital sector because the economic drive of a country is what promotes development and increases in the overall GDP of a country. The economic sustainability dimension contains five main indicators which are economic/values, employment, growth, productivity and initiatives and has been proven to be very important in any urban space. From the result extracted in the table below, all core categories have shown to be very important with the 


\section{IJBPA}

Figure 2.

The graphs of all identified environmental sustainability categories and sub-categories
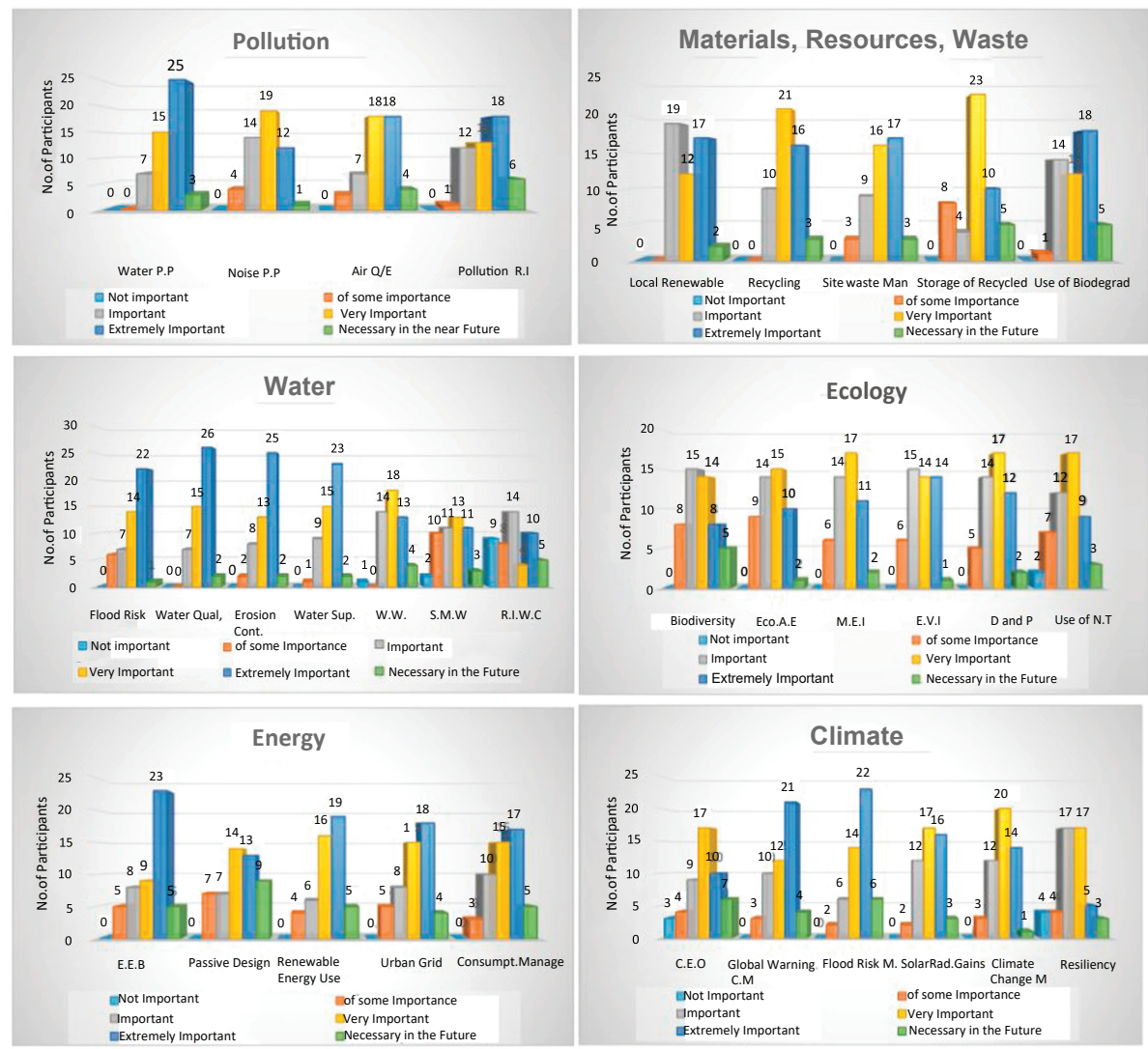

highest indicator on employment, then economic/value followed by growth, then productivity and lastly initiatives. Looking at this analysed data shows that economic sustainability should be given priority compared to other aspects of sustainability. It should be the driving power of future developments in essence; if economic sustainability has been adopted, then other aspects of sustainability which includes social/cultural, planning and environmental will follow.

The mean values for the categories of social dimension are in the range of 3.92 and 4.58, while the standard deviations for the categories are in the range of 0.7769 and 1.1993 which means that there is a satisfying consensus, and the slim gap indicates that the economic dimension has higher priority. The decrease in the standard deviation means that the experts show a movement toward convergence and consensus (Vidal et al., 2011). Table 4 presents the mean values and standard deviations for all categories under the economic dimension as well as their criteria. A low standard deviation indicates that the data points tend to be very close to the mean, and a high standard deviation indicates that the data points spread out over a large range of values.

Figure 3 states the graphs of all identified economic sustainability categories and sub-categories. 


\begin{tabular}{|c|c|c|c|c|c|}
\hline $\begin{array}{l}\text { Sustainability } \\
\text { dimension }\end{array}$ & Core categories & Sub-categories & Mean & $\begin{array}{l}\text { Standard } \\
\text { deviation }\end{array}$ & developmen \\
\hline $\begin{array}{l}\text { Economic } \\
\text { sustainability }\end{array}$ & Productivity & $\begin{array}{l}\text { Affordable housing } \\
\text { Housing demand } \\
\text { Informal sector } \\
\text { Income-generated development } \\
\text { Access to financing } \\
\text { Efficient resources use } \\
\text { Economic activities } \\
\text { New investment } \\
\text { Promoting local industry } \\
\text { Business facilities } \\
\text { Employment opportunities } \\
\text { Justice and equity } \\
\text { Creation of local jobs } \\
\text { Live/work units, local shops, core centres, } \\
\text { factory and social centres } \\
\text { Accessible to everyone } \\
\text { Cost efficiency } \\
\text { Efficient pricing } \\
\text { High quality outcomes } \\
\text { Viability of new infrastructures } \\
\text { Long-term finance schemes } \\
\text { Local context } \\
\text { Politics }\end{array}$ & $\begin{array}{l}4.58 \\
4.42 \\
3.96 \\
4.14 \\
4.10 \\
4.10 \\
3.92 \\
3.92 \\
4.30 \\
3.94 \\
4.46 \\
4.40 \\
4.46 \\
4.06\end{array}$ & $\begin{array}{l}0.7769 \\
0.94 \\
1.0385 \\
1.0002 \\
1.04403 \\
1.19933 \\
1.1536 \\
1.18051 \\
1.11803 \\
1.19013 \\
0.94255 \\
1.01980 \\
0.94255 \\
1.04709\end{array}$ & $\begin{array}{r}\text { Table } 4 . \\
\text { Mean/standard } \\
\text { deviations (economic } \\
\text { dimension) }\end{array}$ \\
\hline
\end{tabular}

\section{Social/cultural sustainability}

Most scholars have described social sustainability as the engagement amongst local communities, employees, clients and all stakeholders involved in the construction project to ensure that it meets the needs of current and future generations (Herd-Smith and Fewings, 2008). The social/cultural dimension has five aspects or main indicators to be considered in this analysis; these are community (culture/empowerment), education, health, equity and security. According to the data collected, the current system in Nigeria has shown that some areas are very poor in regards to education, health and security. Education is seen as the most pressing aspect because knowledge is power, and to build a knowledge-based economy, most of these aspects of sustainability indicators can be adopted more easily without any issue from both urban and rural communities. Health is seen as the second most important indicator to be considered when planning. The built environment includes the physical structures in which people work, live, play and socialise. Another important aspect is the connections between these spaces, including the built infrastructure and a range of natural features used in creating a healthier environment. Other major indicators include housing, neighbourhood conditions and transport routes, all of which shape the social, economic and environmental conditions on which good health is dependent (Dearry, 2004).

Security has shown a significant number of responses; due to the current issues in Nigeria, the safety of citizens is very important. Every individual needs to feel that they are secure from issues like terrorism, theft and vandalism; hence, safety systems, initiatives and features should be placed in urban spaces to enhance the overall safety of its occupants. Community (culture/empowerment) which is the second-to-last aspect looks at how diverse cultures can live in harmony with each other and lastly equity strives to incorporate various strata of people working together, living in unity, thereby providing basic services, facilities and infrastructures for all to use and also creating opportunities for all, no matter what level of income they have. 


\section{IJBPA}

Figure 3.

The graphs of all identified economic sustainability categories and sub-categories
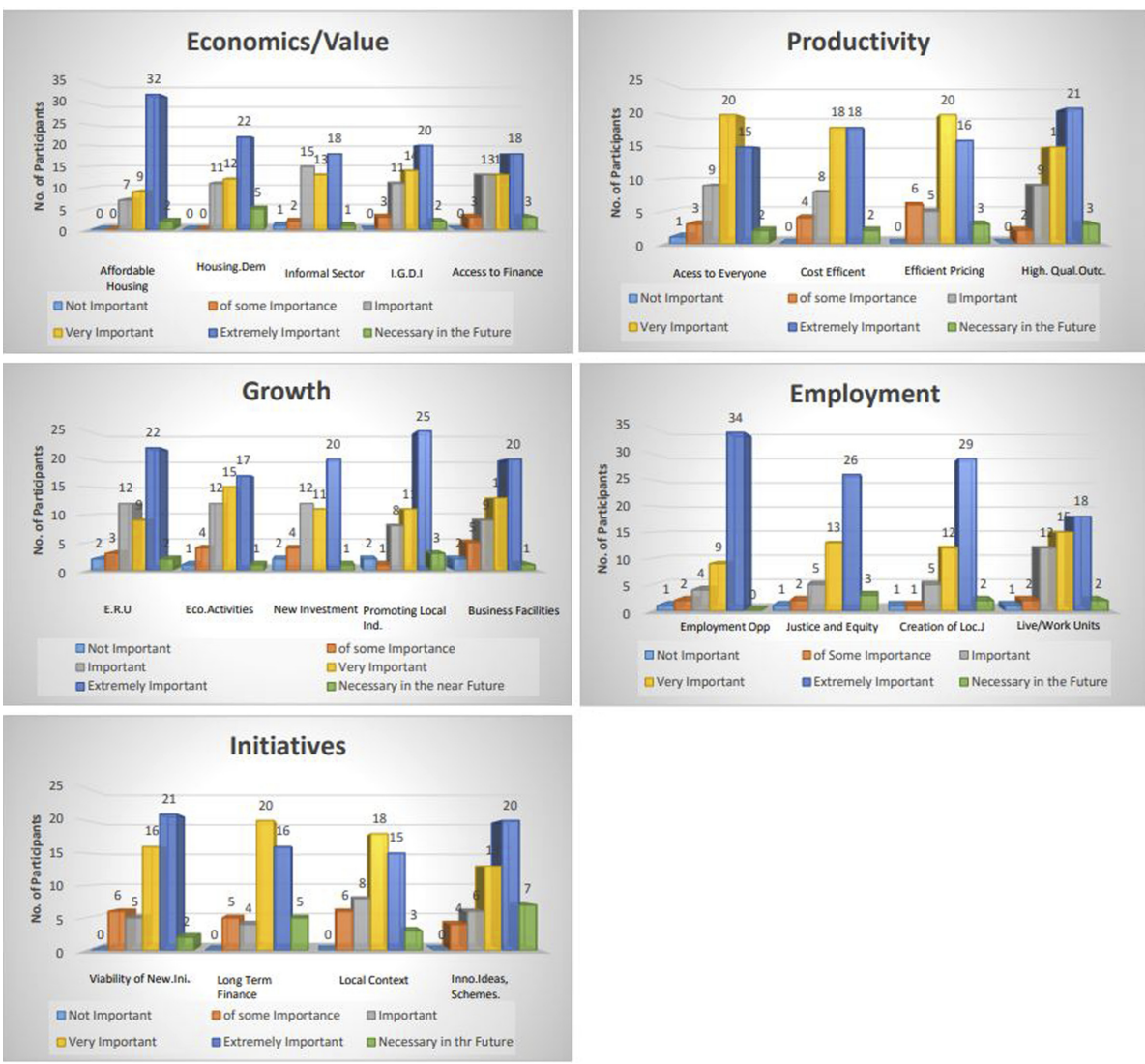

The mean values for the categories of social dimension are in the range of 3.46 and 4.68 , while the standard deviations for the categories are in the range of 0.83522 and 1.41718 , which means that there is a satisfactory consensus and the gap indicates that the social/cultural dimension has the next priority after economic sustainability. The sub-category spans between gymnasium halls which have the lowest factor and clinics which has the highest factor. The decrease in standard deviation means that the experts show a movement towards convergence and consensus. Table 5 presents the mean values and standard deviations for all categories under the social/cultural dimension. The purpose for the assessment indicators selection is focussed on the citizen perspective than a global scientific perspective. Figure 4 states the graphs of the all identified social/cultural sustainability categories and subcategories.

\section{Planning sustainability}

Planning sustainability is a new dimension that has started gaining recognition as a new tier of sustainability in the last decade. Planning sustainability looks at balancing the needs of communities, government and private companies against a range of social, economic and environmental objectives. For planning to be effective, it requires an understanding of the relationships between communities, buildings, cities and climate. In this study, the main 


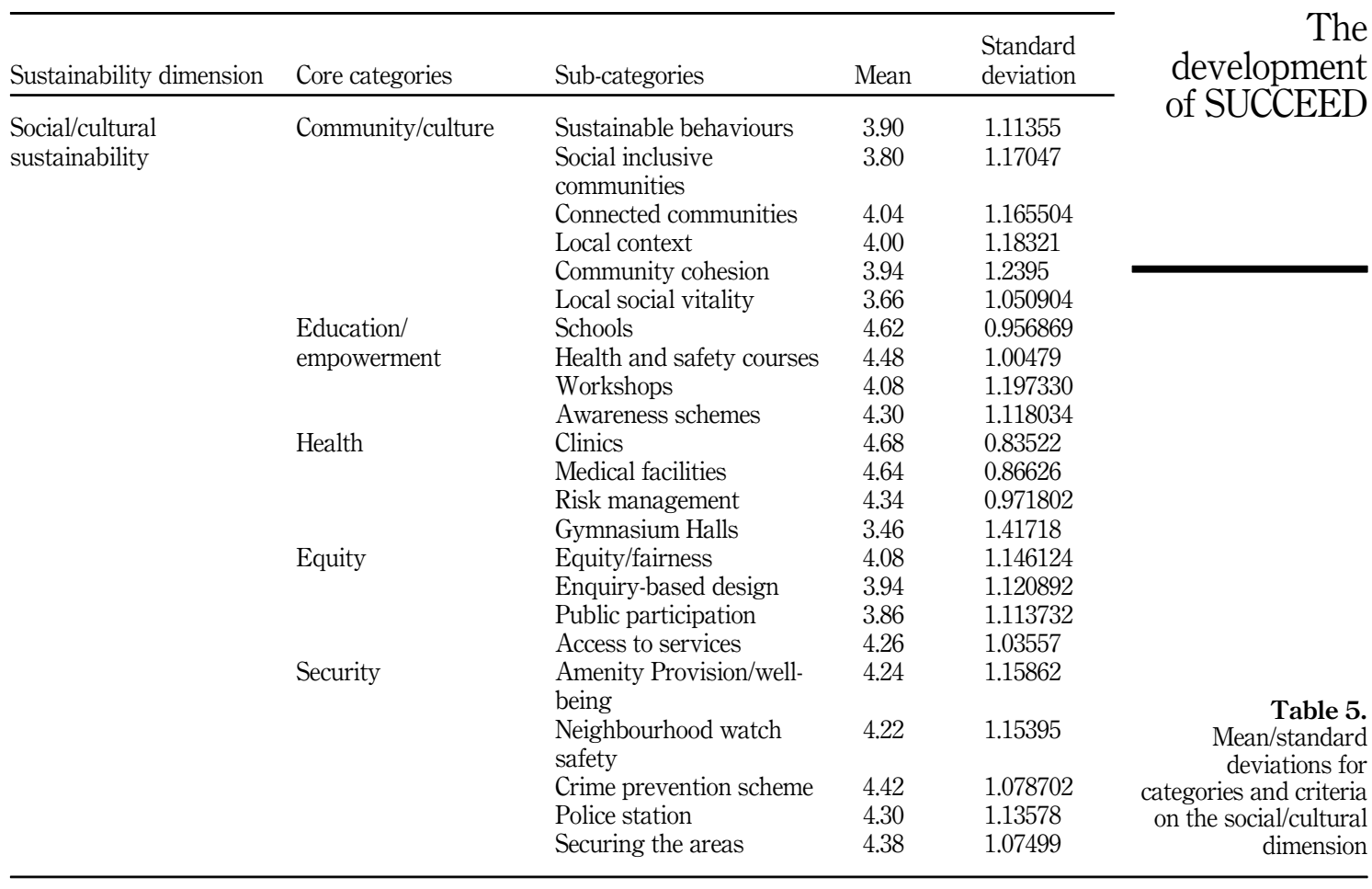

indicators comprise place-making, management, transportation, governance and land use. According to the data collected, land use has attracted large interest with all its sub-indicators having the highest amount of importance. Land use is one of the most important indicators when considering future generations because when building, it is imperative that the designer achieves sustainability through density, for example considering a range of mixeduse developments rather than focussing on the specific typology of building design, thereby utilising a vast area of land. Another interesting area of focus is the transportation system. There is the need for a sustainable alternative means of conveying people from one place to another as well as providing facilities within the urban areas that would reduce the travelling distance to various destinations. Also, the planning of effective use of land will help to reduce congestion and improve journey times.

The third most important indicator is management which is key in every development. For development to thrive for decades, it needs proper management to be carried out to help increase the life span of the buildings and the built-up spaces. Urban spaces have to be driven by efficient management which is known to be a by-product of sustainability; hence, for it to last a long time, it has to be properly managed. Place-making is seen as a multi-faceted approach to planning, design and management of public spaces which emphasise on the local community's assets, aspirations and identities intending to promote people's health, happiness and well-being. Finally, good governance is important in ensuring the smooth running of urban spaces. The sub-indicators that are seen as not relevant based on the questionnaires include homogeneity of houses and car-sharing scheme.

Table 6 presents the mean values for these categories of the planning dimension are in the range of 3.06 and 4.46, while the standard deviations for the categories are in the range of 


\section{IJBPA}

Figure 4.

Graphs of all identified social/cultural sustainability categories and sub-categories
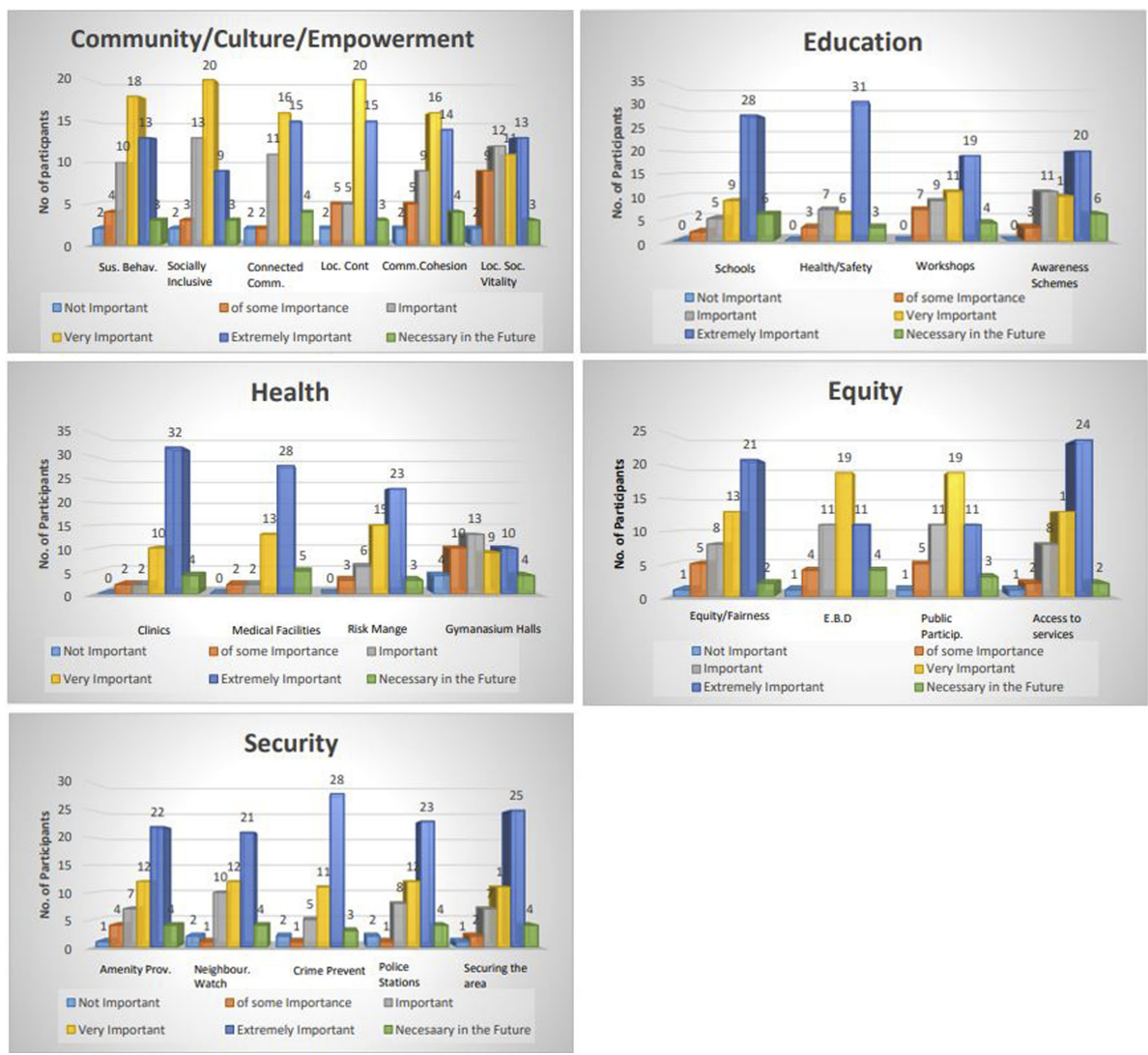

0.85229 and 1.680595 which means that there is a satisfactory consensus. The sub-categories span between homogeneity of houses which has the lowest factor and public transport which has the highest factor. The decrease in the standard deviation means that the experts show a movement toward convergence and consensus. Figure 5 states the graphs of all identified planning sustainability categories and sub-categories.

\section{Conclusion and recommendations}

Sustainable communities have diverse definitions, but it explains how communities are designed, organised, altered and built to support sustainable living. It is vital to note that sustainable communities which is an end product of urban sustainability assessment tend to emphasise on environmental, social, economic, social equity and municipal government to achieve a good quality of life now and in the future (Allen, 2009). To produce an urban space that is truly sustainable, an assessment tool is recommended to embrace sustainability within the environment. The main purpose for the use of sustainability assessment is to generate precise information that decision makers will utilise to create an appraisal on the impacts of both proposed and existing development; also its impact on the environment and global to local changes (Pope et al., 2004). The most effective approach is made by assessing selected individual fields by way of sustainability indicators. The use of indicators from sustainability 


\begin{tabular}{|c|c|c|c|c|c|}
\hline $\begin{array}{l}\text { Sustainability } \\
\text { dimension }\end{array}$ & Core categories & Sub-categories & Mean & $\begin{array}{l}\text { Standard } \\
\text { deviation }\end{array}$ & developmer \\
\hline Planning sustainability & Transportation & $\begin{array}{l}\text { Scale, massing and height } \\
\text { Local materials use } \\
\text { Detailing, frontage, form, orientation } \\
\text { Access to public spaces } \\
\text { Diversity of building typologies } \\
\text { Landscape design } \\
\text { Space for future developments } \\
\text { Facilities management } \\
\text { Building/site maintenance } \\
\text { Monitoring stakeholders control } \\
\text { Operation of design/post-occupancy } \\
\text { Site and services approach to housing } \\
\text { Public transport } \\
\text { Traffic management scheme } \\
\text { Cycling/pedestrian/street network } \\
\text { Car-sharing schemes } \\
\text { Smart location } \\
\text { Proximity to community services } \\
\text { Walk-able/human-scale } \\
\text { Transit-oriented design of } \\
\text { communities } \\
\text { Environment } \\
\text { Local context } \\
\text { Politics } \\
\text { Civil society } \\
\text { Local planning approval } \\
\text { Increasing sustainability by density } \\
\text { Green spaces } \\
\text { Residential schemes } \\
\text { Business area and public services } \\
\text { Effective use of land } \\
\text { Compact development } \\
\text { Homogeneity of houses }\end{array}$ & $\begin{array}{l}3.88 \\
3.74 \\
3.78 \\
3.86 \\
3.88 \\
3.94 \\
4.34 \\
3.88 \\
4.24 \\
3.78 \\
3.88 \\
3.94 \\
4.46 \\
4.44 \\
4.22 \\
3.34 \\
3.58 \\
4.08 \\
3.90 \\
3.98 \\
\end{array}$ & $\begin{array}{l}1.3948 \\
1.1280 \\
1.13649 \\
1.2167 \\
1.12499 \\
1.12089 \\
1.2745 \\
1.1634 \\
1.04995 \\
1.28515 \\
1.33626 \\
1.19013 \\
1.080926 \\
0.85229 \\
1.17115 \\
1.680595 \\
1.401285 \\
1.18051 \\
1.3000 \\
1.25682\end{array}$ & $\begin{array}{r}\text { Table } 6 . \\
\text { Mean/standard } \\
\text { deviations for } \\
\text { categories and criteria } \\
\text { on the planning } \\
\text { dimension }\end{array}$ \\
\hline
\end{tabular}

can assist decision-makers to be more aware of the impact of prospective developments based on data-driven decisions. The data extrapolated from the questionnaires were used in designing SUCCEED-ND which was designed by using indicators based on the Nigerian context. This research project was based on six urban sustainability assessment tools which include LEED-ND, BREEAM Communities, CASBEE UD, Green Star for Communities, SuBETool, SUPD and Green Economy Indicators. The assessment was also based on indicators selection, prioritisation, weighting scheme and validation process using Delphi methodology and a panel of professionals from academic, practitioners and government officials. A total of 105 indicators were used in designing the sustainability assessment tool based on a mean value of 3.32-4.68 (see Table 7).

The data collated were based on a methodological approach that focusses on the most vital indicators that were utilised to generate recommendations and contribution to knowledge with regards to sustainability assessment and sustainable urban futures. This also affirms that sustainability indicators differ by context, culture and region. In developing societies, sustainability is perceived to have more relevance within the social and economic dimension, while the environmental dimension is seen to have lesser relevance. The overall 


\section{IJBPA}

Figure 5.

The graphs of the all identified planning sustainability categories and sub-categories
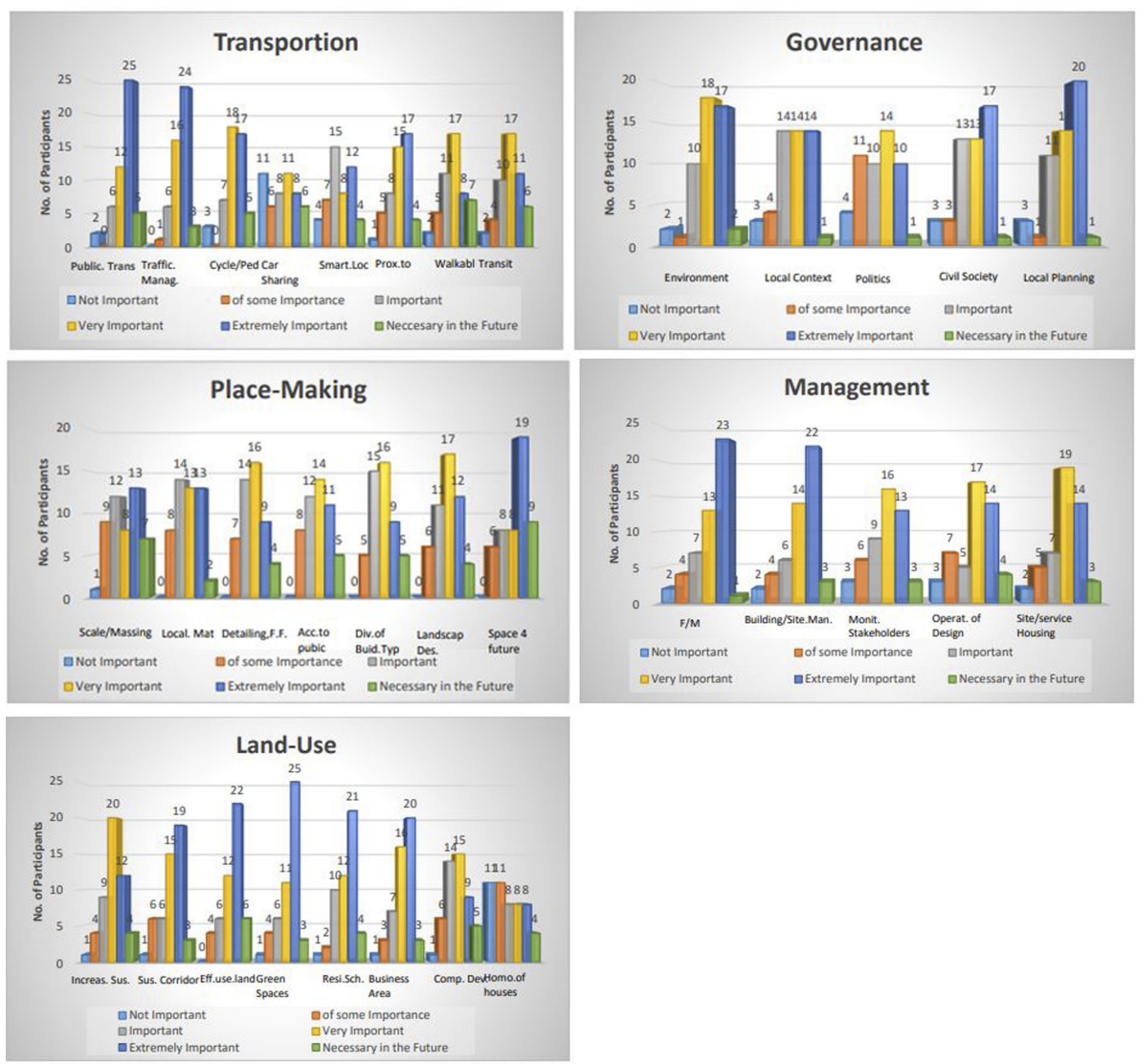

rating which will influence the assessment tool would be influenced by the number of indicators achieved on each sustainability criteria. Hence, a project would be graded based on the total summation of these indicators. This assessment method is one of the major contributions in this research.

In conclusion, the analysed data were used in influencing the proposed SUCCEED-ND assessment tool. Overall, it is necessary to create an understanding of this scheme in terms of its assessment criteria, indicators, scope and performance criteria, critiquing this tool as well as creating a tool suitable for developing countries (Lee et al., 2008; Hernandez et al., 2008; Aguiar et al., 2020). This developed NSA tool dictates different methods of designing city and neighbourhood development, as well as the selection of the categories, criteria and indicators. Furthermore, these frameworks were developed for the Nigerian environment based on the data collected from that region, the current circumstances in developing countries and other different reasons. The overall goal of this model is to achieve sustainable urban development which should also include the following set of recommendations:

(1) Adopting good urban governance as a priority will promote functional cities for rapid economic growth. 
Environmental

sustainability

Pollution

Materials, resources and waste

Water

Ecology

Energy

Climate

Social/cultural

sustainability

Community/culture

Health

Equity

Security

\begin{tabular}{l} 
Economic sustainability \\
\hline Economics/value
\end{tabular}

Growth

Employment

Productivity

Initiatives

Planning sustainability

Place-making

Management

Transportation

Governance

Land-use
SUB - categories' indicators

Water pollution and noise pollution prevention, air quality enhancement, pollution innovation

Local renewable materials, recycling and innovation, site waste management schemes, storage of recycled waste, reuse of materials, structure and infrastructure, longevity, use of biodegradable materials

Flood risk, water quality, erosion control, responsible water supply initiatives, wastewater management, smart metering-water, reduction in water consumption daily

Biodiversity, biophilia, ecological appraisal, ecology innovation, eco-system enhancement, minimising ecological impact, topography alteration/protecting ecological value, diversity and preservation, use of natural topography

Energy efficient building, passive/active designs, renewable energy generation and use, urban grid optimisation, consumption management

Climate emissions, global warming, flood risk mitigation, solar radiation, climate change (vulnerability and adaption, resiliency)

\section{Sub-categories' indicators}

Sustainable behaviours, involvement demographics, social inclusive communities Connected communities, local context, community cohesion, local social vitality (local Housing authority, supranational assistance organisation (United Nations)), local lifestyle (Embracing it, integrating it-for example, grounding place, local gardens, playgrounds, saga Spots)

Schools, facilities, health and safety courses, workshops, awareness schemes Clinics, medical facilities, access to services, gymnasium Halls

Equity/fairness, enquiry-based design, public participation, services

Amenity/well-being, neighbourhood safety, crime prevention, police stations, risk Management, securing the areas

Sub-categories indicators

Affordable housing, housing demand, informal sector, local economy, income/ spending, access to financing, credit, loans, and mortgages to build individual limits Efficient resources use, economic activities, new investment, promoting local industry, business facilities

Employment opportunities, economic capacity, justice and equity, economic capacity, creation of local jobs (some live and work units, local shops, clinics, core centres, social centres, offices, superstores, factory and other facilities, gymnasiums) Accessible to everyone, cost efficiency, efficient pricing, quality Viability of new infrastructures, long-term finance schemes, local context, politics

Sub-categories indicators

Scale, massing/height, local materials, details, frontage, access to public spaces, diversity of building typologies, quality of streetscapes, landscape design, space for future developments

Facilities management, building/site maintenance, monitoring stakeholders control, operation, site and services approach to housing provision (where government provides services such as roads, utilities and basic building framework)

Public transport, traffic management, sustainable Mass transit, cycling network, pedestrian network, car sharing schemes, smart location, street network, proximity to community services, walk-able, human-scale, transit-oriented

Environment, local context, politics, civil society, local planning approval Increasing sustainability through density, sustainable corridors, green spaces, residential schemes, public services, effective use of land, business area, housing density, compact development, homogeneity of houses (courtyards, duplex, triplexes and galleries)

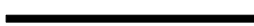


(2) Promoting the assessment tool by the Green Building Council of Nigeria for it to be used for both existing and proposed development.

(3) Developing a software-based tool or application for SUCCEED-ND alongside readopting the tool to be used in other developing countries.

(4) Explore how this assessment tool can collaborate with existing tools like BREEAM communities, LEED-ND and Green Star, as well as collaboration with key players within the field of sustainable urbanism.

(5) Development of SUCCEED-ND on other projects for example building and city-scale projects.

(6) Providing measures on how to increase awareness on sustainability assessment through hosting webinars, workshops, symposiums and conferences.

(7) Providing adequate hands-on training that can be used to equip professionals to aid the adoption of sustainability assessment.

(8) Future development and master plan can be designed and reviewed following the SUCCEED-ND key indicators.

\section{References}

ABGR (2015), Green Star and Australian Building Greenhouse Rating Scheme, Australian Building Greenhouse Rating, available at: www.abgr.com.au/new/default.asp (accessed 21 March 2015).

Aguiar, A.P.D., Collste, D., Harmackova, Z.V., Pereira, L., Selomane, O., Galafassi, D., Van Vuuren, D. and Van Der Leeuw, S. (2020), "Co-designing global target-seeking scenarios: a cross scale participatory process for capturing mutiple perspectives on pathways to sustianability", Global Environmental Change, Vol. 65, 102198.

Ajayi, D. and Chris, I. (2005), “An analysis of Nigeria's environmental vision”, 2010 Published in the Journal of Environmental Policy and Planning, Vol. 7 No. 4, pp. 341-365.

Allen, A. (2009), "Sustainable cities or sustainable urbanisation", University College London Journal of Sustainable Cities Summer 2009, Vol. 1, pp. 1-3.

Alwaer, H., Bickerton, R. and Kirk, D. (2013), "Examining the components required for assessing the sustainability of communities in the UK", Journal of Architectural and Planning Research.

Alqahtany, A.M., Rezgui, Y. and Li, H. (2013), "A proposed model for sustainable urban planning development for environmentally friendly communities", Architectural Engineering and Design Management, Vol. 9 No. 3, pp. 176-194, doi: 10.1080/17452007.2012.738042, ISSN 1745-2007.

Ameen, R.F.M. and Mourshed, M. (2019), "Urban sustainability assessment framework development: the ranking and weighting of sustainability indicators using analytic hierarchy process", Sustainable Cities Society, Vol. 44, pp. 356-366.

Balsas, C.J.L. (2004), "Measuring the liveability of an urban centre: an exploratory study of key performance indicators", Planning Practice and Research, Vol. 19 No. 1, pp. 101-110.

Bragança, L., Mateus, R. and Koukkari, H. (2010), "Building sustainability assessment”, Sustainability, Vol. 2 No. 7.

BRE (2008), A Discussion Document Comparing International Environmental Assessment Methods for Buildings BRE, Glasgow.

BRE (2017), What Is BREEAM? [Online], Building Research Establishment (BRE), available at: http:// www.breeam.com/. 
Castanheira, G. and Braganca, L. (2014), "The evolution of the sustainability assessment tool: from buildings to the built environment", Hindawi Publishing Corporation: The Scientific World Journal, Vol. 2014, 491791, doi: 10.1155/2014/491791.

Cole, R.J. (1999), “GBC' building environmental assessment methods: clarifying intentions”, Building Research and Information, Vol. 27 Nos 4/5, pp. 230-246.

Curwell, S., Deakin, M. and Lombardi, P. (2005), "The bequest framework: a vision and methodology", Sustainable Urban Development: The Framework and Protocols for Environmental Assessment, Routledge, Vol. 1, pp. 19-42, London.

Dearry, A. (2004), "Editorial: impacts of our built environment on public health", Environmental Health Perspectives, Vol. 112 No. 11, p. A600.

D'Acci, L. and Lombardi, P. (2010), "MuSiC. A new multi-scalar index for evaluating sustainability in cities", in Lehmann, S., Alwaer, H. and Al-Qawasmi, J. (Eds), The Second International Conference on Sustainable Architecture and Urban Development: The Centre for the Study of Architecture in the Arab Region Publications (CSAAR), Amman, ISSN 1992-7320, Vol. 3, pp. 19-34.

European Urban Knowledge Network (2014), EUKN EGTC Policy Lab Sustainable Neighborhood Ranking Systems Luxembourg, June 30, 2014, available at: www.eukn.eu.

Federal Government of Nigeria (2012), "Nigeria's path to sustainable development through green economy", Country Report to the Rio + 20 Summit June 2012.

Fowler, M. and Rauch, M. (2006), "Sustainable building rating systems summary: in contract July 2006 for the, United States Department of Energy".

Green Building Council Australia (GBCA) (2012), available at: http:/www.gbca.org.au/greenstar/ rating-tools/ (accessed 15 July 2021).

Gibberd Jeremy (2002), "Assessing sustainable building in developing countries the sustainable building assessment tool (SBAT) and the sustainable building lifecycle (SBL) CSIR, Building and Construction Technology".

Happio, A. (2012), "Towards sustainable urban communities", Article in Environmental Impact Assessment Review, Vol. 32 No. 1, pp. 165-169.

Haapio, A. and Viitaniemi, P. (2008), "A critical review of building environmental assessment tools", Environmental Impact Assessment Review, Vol. 28, pp. 469-482, doi: 10.1016/j.eiar.2008.01.002.

Harold, A.L. and Turoff, M. (1975), The Delphi Method: Techniques and Applications, Addison-Wesley, Reading, Mass, 978-0-201-04294-8, archived from the original on 2008-05-20.

Herd-Smith, A. and Fewings, P. (2008), The Implementation of Social Sustainability in Regeneration Projects: Myth or Reality?, Royal Institution of Chartered Surveyors, London, available at: http:// www.rics.org/site/scripts/download_info.aspx?fileID $=3178 \&$ categoryID $=52$ (accessed 3 November 2009).

Hernandez, P., Burke, K. and Lewis, J. (2008), "Development of energy performance benchmarks and building energy ratings for non-domestic buildings: an example for high primary schools", Energy and Buildings, Vol. 40, pp. 249-254.

IBEC (2017), Comprehensive Assessment System for Built Environment Efficiency (CASBEE) [Online], Japan Sustainable Building Consortium (JSBC) and Institute for Building Environment and Energy Conservation(IBEC).

Idowu Oyeleye Oyewale (2013), "Challenges of urbanisation and urban growth in Nigeria", America Journal of Sustainablecities and Society, Vol. 1 No. 2, pp. 79-95.

Kyrkou, D., Taylor, M., Pelsmakers, S. and Karthaus, R. (2011), "Urban Sustainability assessment systems: how appropriate are global sustainability assessment systems?", PLEA 2011-27th Conference on Passive and Low Energy Architecture, Louvain-La-Neuve Belgium, 13-15 July 2011.

Lee, S.H., Han, J.H., Leem, Y.T. and Yigitcanlar, T. (2008), “Towards ubiquitous city: concept, planning, and experiences", Igi Global, Vol. 2, pp. 148-169. 
Lindseth, G. (2004), "The cities for climate protection campaign (CCPC) and the framing of local climate policy", Local Environment, Vol. 9 No. 4, pp. 325-336.

Loh, J. (2000), The Living Planet Report 2000, pub WWF, Gland, p. 1, 2000.

Lombardi, P. and Cooper, I. (2009), "The challenge of the e-Agora metrics: the social construction of meaningful measurements", International Journal of Sustainable Development, Vol. 12 No. 2, pp. 210-222.

McKenzie Stephen (2004), "Social sustainability. Towards some definitions”, Working Paper series 27 (2004), Hawke Research Institute.

Momoh, J. (2016), “Sustainability urbanism and it assessment”, Unpublished PhD Thesis, Nottingham Trent University.

Moussiopoulos, N., Achillas, C., Vlachokostas, C., Spyridi, D. and Nikolaou, K. (2010), "Environmental, social and economic information management for the evaluation of sustainability in urban areas: a system of indicators for Thessaloniki, Greece", Cities, Vol. 27 No. 5, pp. 377-384.

National Urban Development Policy (2012), The Revised National Urban Development Policy Was Approved by the Federal Executive Council on 20th June, 2012, Produced by the Federal Ministry of Land, Housing and UrbanDevelopment Mabushi, Abuja.

Pope, J., Annandale, D. and Morrison-Saunders, A. (2004), "Conceptualising sustainability assessment”, Journal of Environmental Impact Assessment Review, Vol. 24, pp. 595-616, 2004.

Reed, R., Wilkinson, S. and Anita, B. (2011), "A comparison of international sustainable building tools - an update", The 17th Annual Pacific Rim Real Estate Society Conference, Gold Coast 16-19 January 2011.

Roderick, Y., McEwan, D., Wheatley, C. and Alonso, C. (2011), "Comparison of energy performance assessment between LEED, BREEAM and Green Star", Building Simulation 2011, Eleventh International IBPSA Conference Glasgow, Scotland, July 27-30, 2011.

Sharifi, A. (2021), "Urban Sustainability Assessment: an overview and bibliometric analysis", Published in the Journal of Ecological Indicators, Vol. 121, 107102, doi: 10.1016/j.ecolind.2020. 107102, Feb 2020.

Sharifi, A. and Murayama, A. (2015), "Viability of using global standards for neighbourhood sustainability assessment: insights from a comparative case study", Journal of Environmental Planning and Management, Vol. 58 No. 1, pp. 1-23.

Sleeuw, M. (2011), "A comparison of BREEAM and LEED environmental assessment methods”, A report to the university of East Anglia Estates and Building November 2011.

Svarstad, H., Petersen, L.K., Rothman, D., Siepel, H. and Wätzold, F. (2008), "Discursive biases of the environmental research framework DPSIR", Land Use Policy, Vol. 25 No. 1, pp. 116-125.

Todd, J.A. and Geissler, S. (1999), "Regional and cultural issues in environmental performance assessment for buildings", Building Research and Information, Vol. 27 Nos 4/5, pp. 247-256.

UN Habitat - For a better urban future (2009), "Climate change [www] URL”, downloaded: 2014-05-01, available at: http://unhabitat.org/urban-themes-2/climate-change/.

United Nations, Department of Economic and Social Affairs, Population Division (2015), World Urbanisation Prospects. The 2015 Revisions, Highlights (ST/ESA/SER.A/352).

USGBC (2011), LEED for Neighbourhood Development [Online], US GREEN BUILDING COUNCIL, available at: http://www.usgbc.org/DisplayPage.aspx?CMSPageID $=148$.

Vidal, L.-A., Marle, F. and Bocuet, J.-C. (2011), "Using a Delphi process and the analytic hierarchy process (AHP) to evaluate the complexity of projects", Expert Systems with Applications, Vol. 38, pp. 5388-5405.

Wang, Y., Chen, P.-C., Ma, H.-W., Cheng, K.-L. and Chang, C.-Y. (2016), Socio-economic Metabolism of Urban Construction Materials: A Case Study of the Taipei Metropolitan Area.

Warhurst, A. (2002), "Sustainability indicators and sustainability performance management", Report to the Project: Mining, Minerals and Sustainable Development (MMSD), International Institute 
for Environment and Development (IIED), Warwick, available at: http://www.iied.org/mmsd/ mmsd_pdfs/sustainability_indicators.pdf.

Wong, S.-C. and Abe, N. (2014), "Stakeholders' perspectives of a building environmental assessment method: the case of CASBEE", Building and Environment, Vol. 82, pp. 502-516.

Wu, J. (2014), "Urban sustainability: an inevitable goal of landscape research", Landscape Ecology, Vol. 25, pp. 1-4.

Xing, Y., Horner, R.M.W., El-Haram, M.A. and Bebbington, J. (2009), "A framework model for assessing sustainability impacts of urban development”, Journal of Accounting Forum, Vol. 33, pp. 209-224.

Zilans, A. and Abolina, K. (2007), “A methodology for assessing urban sustainability: Aalborg commitments baseline review for Riga”, Latvia. Environment, Development and Sustainability, Vol. 11 No. 1, pp. 85-114.

Zimmerman, A. and Kibert, C.J. (2007), "Informing LEED's next generation with the Natural Step", Building Research and Information, Vol. 35 No. 6, pp. 681-689.

\section{Further reading}

Bentivegna, V., Curwell, S., Deakin, M., Lombardi, P., Mitchell, G. and Nijkamp, P. (2002), "A vision and methodology for integrated sustainable urban development: BEQUEST", Building Research and Information, Vol. 30 No. 2, pp. 83-94.

Borges, A., Hammami, F. and Wangel, J. (2020), "Reviewing neighbourhood sustainability assessment tools through critical heritagae studies", Sustainability, Vol. 12, p. 1605.

Grace, M. (2000), "BREEAM- A practical method for assessing the sustainability of buildings for the new millennium", International Conference Sustainable Building, October 2000, Maastricht the Netherlands, The Netherlands: In-house Publishing, Vol. 200, pp. 22-25.

Haapio, A. (2008), "Environmental assessment of buildings", PhD Forest Products Technology, Helsinki University of Technology.

Hernandz, P., Burke, K. and Lewis, J. (2008), "Development of energy performance benchmarks and building energy ratings for non-domestic buildings: an example for high primary schools", Energy and Buildings, Vol. 40, pp. 249-254, 2008.

Husam, A., Bickerton, R. and Kirk, R.D. (2013), "Examining the components required for assessing the sustainability of communities in the UK", Journal of Architectural and Planning Research, Locke Science Publishing Company, Vol. 31 No. 1 (Spring, 2014), pp. 1-26.

Lee, Y. (2012), 'Indicators for Sustainability' How Cities are Monitoring and Evaluating their Success Canadian International Development Agency (CIDA).

Roderick, Y., McEwan, D., Wheatley, C. and Alonso, C. (2009), "Comparison of energy performance assessment between LEED, BREEAM and green star", Building Simulation 2009, Eleventh International IBPSA Conference Glasgow, Scotland July 27-30, 2009.

United Nations (2015), Department of Economic and Social Affairs, Population Division. World Urbanization Prospects: the 2014 Revision, Highlights, United Nations, New York, NY.

\section{Corresponding author}

Job Momoh can be contacted at: momohj@1sbu.ac.uk

For instructions on how to order reprints of this article, please visit our website:

www.emeraldgrouppublishing.com/licensing/reprints.htm

Or contact us for further details: permissions@emeraldinsight.com 